\title{
A Brief Discussion on Formation of Zangmi Tancheng Art
}

\author{
Jianxun Yuan \\ Hezuo National Normal Advanced School \\ Hezuo, Gansu, China 747000
}

\begin{abstract}
In this paper, the author analyzed the formation of Tantric history of Tibetan Buddhism and other cultural elements in Zangmitancheng art. It points out that Zangmitancheng art is one kind of brand-new art which it on basis of Yinmitancheng and it incorporating BonPo culture and Han culture.
\end{abstract}

Keywords-Zangmi; Tancheng; BonPo; art

\section{INTRODUCTION}

In Zangmi art, Tancheng is regarded as the most sacred, mysterious and characteristic representative of religious art, for the practicing monks, it is the communication to "visualize" the gods, and practitioners can reach the Spiritual World and communicate with gods through Tancheng. For the general believers, it is a sacred object to worship the god and Buddha. In religious activities, it is an important tool for Zangmi practice. It is also a symbol existing everywhere in the Tibetan Buddhist art. The study of the Zangmi Tancheng culture and art can not only deepen the understanding of Zangmi art and art history, but also deepens the understanding of the essence and connotation of Tibet Plateau culture in a deeper sense.

\section{THE FORMATION OF ZANGMI}

To a certain extent, Tibetan Buddhism is a continuation of Indian Buddhism, especially the "Tibetan Tantrism in the second propagation mainly faithfully inherited Indian Tantrism after the 11th century". What's more, Zangmi seriously absorbed, developed and transformed the classics, practice, sequence, ritual of Indian Tantrism and deities worshiped by it, which integrated Indian Tantrism with plateau BonPo, and formed the unique Tantrism with characteristics of Tibet.

At the beginning of the 7th century, the Tibetan King Srongtsen Gampo established a powerful slavery Tibetan Empire on the Tibet Plateau. The Buddhism adapted itself to the new historical choice, and began to enter the Tibet Plateau in large scale. At this time, the Indian Buddhism had entered the period of "pure Tantrism". The introduction of Indian Buddhism to Tibet was directly manifested as the sweeping of Indian Tantrism. According to the Tibetan history books, at that time, more than a dozen $\mathrm{f}$ small temples were built in Lhasa, such as Jokhang Temple, Ramoche Temple and Gaza, in which a lot of statues were worshiped, including Sakyamuni, Maitreya, Avalokitesvara, Tara, Mother Buddha, Bright Mother Buddha, Sarasvati, Horse-necked Avalokitesvara and Ganlumingwang, and also there is statue of Pan-Tantrism.
However, the introduction of Tantrism to Tibet had encountered a problem of the relation with BonPo culture which had a long history at the beginning. Tantrism chose to attach itself to BonPo with a tolerant attitude, and reached it tentacles into the hearts of believers to strive for understanding and sympathy. For example, when constructing Jokhang

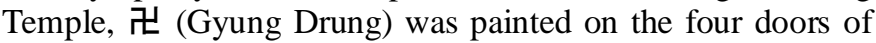
the temple to entertain BonPo believers, and check (one of BonPo patterns) was painted to entertain civilians." But such tolerance and attachment destined the weak personality of Buddhism and the inheritance of BonPo spirit from the beginning [2].

Up to the 8th century, after a fight between Buddhism and BonPo which presented as religious dispute but was political and power division essentially, BonPo still held sway over the plateau with its invincible stubborn forces. At this time, the emerging powers of Buddhism, who refused to let go of the budding forces and welcomed Padmasambhava who was famous in Buddhism in the name of "Esoteric Buddhism Master" to Tibet to promote Buddhism. Padmasambhava was the son of Takenori Yarra of Orissa, the founder of Indian Mahayana Tantric Vajrayana, the brother-in-law of Santarakshita. Padmasambhava was a forward-looking and down-to-earth Tantrism propagandist and practicer. $\mathrm{He}$ brought Indian Indrabhuti (i.e. Vajrayana Tantrism) into Tibet, and also brought the Highest Yoga Tantra containing the supreme stage of Tantrism' four Dharmas. Padmasambhava had a special important position in the development history of Tibetan Tantrism, who laid the foundation of Zangmi heritage. Firstly, he changed the strategy of fighting with BonPo, changed the opposite attitude of Buddhism and BonPo in politics, turned to start from Tantrism, and actively absorbed some of the principles, dharma and system of BonPo and the deities worshiped by it, making way for Buddhism. Every time Padmasambhava defeated some of the sorcerers of BonPo, he proclaimed that some deities of BonPo had been surrendered and apotheosized as a Buddhist guardian, showing the tolerance of Buddhism. Secondly, he was a tonsured Tibetan monk, and established a standard monastery - Samye, widely translating Exoteric and Esoteric books and imparting Tantrism dharma. According to historical data, there were five "Dakinis" practicing the Highest Yoga Tantra with Padmasambhava at that time. Trisong Detsen and the Princess also learned Lotus Horse-necked Dharma and Dorje Phurba. The establishment of the monastery provided the Buddha with the "Pure Land" to face the believers; and the spread of the 
Tantric practice directly induced the formation of the artistic image of the Zangmi Tancheng, which provided the real subject matter for shaping artistic images of Tantrism. Thirdly, Padmasambhava himself was also a master and active advocate of Tantric art. According to the legend, when Samye Temple was being constructed in the 8th century, Padmasambhava was the first to dance the sorcerer's dance.

In "the second propagation of Buddhism" in the history of Tibet, a great religious reform themed on fusion of Tantrism and BonPo was set off. From the perspective of BonPo, it was Chen Klu Ggav (AD 996 - 1035) who made great contribution to the promotion of the fusion of Tantrism and BonPo. According to BonPo's legends, he was the descendant of BonPo founder Tonpa Shenrab. Chen Klu Ggav was an outstanding religious master who understood the times, who faced the unstoppable re-revitalized Buddhist forces and timely reformed BonPo in form and regarded the supreme Buddha Sakyamuni as the incarnation of Tonpa Shenrab, extolling that he had the ability to guide "all friendships" out of the sea of misery and Samsara; he practices what he preaches and taught his disciples to study Tantric doctrine, seek common points and reserve difference while practicing the Great Perfection. However, the BonPo-Buddhism movement led by Chen Klu Ggav was essentially a reform "in form but not in content", which brought the spirit of BonPo to the blood of Buddhism culture in the appearance of Buddhism, but not really shook the foundation of BonPo.

From the view of Buddhism, it was not optimistic because of the arrival of the "the second propagation"; the historical lesson summed up in the horror, turbulence and uneasiness of more than 100 years had revealed that Buddhism must start from the reality of BonPo culture with a long history and abundant foundation of the masses to adapt to the new historical choice, and absorb BonPo and use by itself to achieve "long-term stability." During this period, it was Rinchen Zangpo (AD 958 - 1055) and Atisha (AD 982 - 1054) who made the major contributors to the integration of Buddhism and BonPo and laid foundation for Zangmi. Rinchen Zangpo had been appointed by Yixiwo of Guge Dynasty, and went to India and Nepal to study Tantrism for three times. Later he devoted himself to the translation of Tantric scriptures, especially 108 Tantric incantations, which made him the symbol of Tantric development in "the second propagation". If we say that Rinchen Zangpo opened the way for the renaissance of Tantrism in "the second propagation", then Atisha was the true achiever that got the leading role of Tantrism in "the second propagation".

After a vigorous religious reform from the tenth to eleventh century, a new religious form, "Tantrism-BonPo" and its various sects, stood in the snow-covered plateau like peaks. Each sect experienced hundreds of years of mutual struggle and growth and decline, and until the fifteenth century, Gelugpa rose abruptly with overwhelming trend, marking the maturity of Tibetan Buddhism."... It had perfect theoretical system, strict organization and unique verifying method, which can be said to be further deepening of the combination of Indian Vajrayana Tantrism with local Tibetan culture"[3].

\section{THE FACTOR OF BONPO IN ZANGMI TANCHENG ART}

Tancheng was the way for practitioners to communicate to the gods, through which they can reach the Spiritual World and communicate with gods. However, the ideological source of such way to communicate with the gods can be found in early primitive religion and the dharma of BonPo in Tibet. The ancient Tibetan primitive religion and the nature worship and animism of BonPo worship thought that: the gods often gathered on something in somewhere, they were the guardian angel of human and needed be to worshiped at all times, so the primitive sacrificial site, altar and rituals came into being. At the same time, that the primitive religion thought that the wizard had supernatural powers, which was bridge between the world and the Divine Divinity, the witchcraft was the way people communicated with God, and the spell was a dialogue with the gods. The primitive BonPo developed and enriched the concept of god-man communication of primitive religion; later, "Jiu Cheng Jing Lun" generated during the systematization period of BonPo reflected the various rituals of BonPo, most of which were absorbed by Nyingma and other sects [4].

There were all sorts and great numbers of Tantric Yidam statues in Zangmi Tancheng, which all shew real body and anger body. The "praising" god worship and rich imagination of "praise" of primitive Tibetan BonPo provided a wealth of material for the ever-changing and grotesque Buddha images of Tantrism.

Tancheng was not only a symbol of the wisdom and virtue of Yidam, but also a visual display of Buddhist universal truth. The world structure and the five major ideas (land, water, fire, wind, air) contained by it was familiar to BonPo. In the ancient book "Genesis" spread in BonPo, the five original substances that made up the world had been put forward, namely wind, fire, dew, dust and mountain. "Genesis" said that long long ago, there was a king named NanKaDongDanQueSong who had five essential substances, and Master ChiJieQuBa collected the five original substances from him and put into his body. He blew gently and the wind began to blow up, and when the wind rotated, the fire appeared. As a result, the heat of the fire and the cold of wind met, and dew emerged. On the dew emerged the dust, which was blown together by the wind and gathered into a mountain. The world was created by Master ChiJieQuBa in this way. "Genesis" saw through a primitive nature worship, whose legacy continued to the ritual, idol, symbol and instrument of BonPo and Tantrism, such as the symbol $\rightleftarrows$, floating curtain, prayer flag, the Wheel of the Law, Marnyi Stone, burning aromatic plant, plodding around mountains and so on.

In Zangmi Tancheng art, man and woman embrace each other on the lotus seat. Zangmi practitioners have their own interpretation on connotation of such two-sex twin-tiered fetus image, rather than various understanding among Zangmi practitioners.

According to the principle of practicing Zangmi, "Union of happiness" is a special practicing method of Highest Yoga Tantra of Zangmi. Exotoric Buddhism took lust as antarayiko dhammo, strictly prohibited "sex", and pursued for "cleanness" 
and rejected "pollution". The Highest Yoga Tantra took "Union of happiness" as the practicing method, endowed sex ("pollution") with mysterious color and the "taming" concept, which was a way to achieve "self sexual cleanness". Tantric practitioners took Vajra Master as father, and his female partner as mother, and they also took the "man and woman's joy" as the way to "get evil". Therefore, women appeared in the Tantric Vajrayana as offerings, and those "women gods" who were known as "BuMu" and "MingFei" in the Tantric ministries were spouse, and thus produced a lot of double-body siamesed idols and Tantric terminologies. Such double-body siamesed idols reflected a philosophical concept of Zangmi, which regarded all the contradiction categories like the good and evil, Yin and Yang, true and false, beauty and ugliness, happiness and bitterness, love and hate, friendliness and protest, indulging and abstinence of life as the poles of men and women in the moving unity, which constituted the universe, the world and life, so this concept was brought into the image of bisexual double-body siamesed image. Many scholars believe that Tantric double-body practicing method and the thought of "great happiness" derived from Shaktism in Hinduism. However, this method had its internal soil and the basis of its national culture in dissemination and development Zangmi. The concept of yin-yang union, sexuality worship and female worship in the two-body practicing method was originally the universal existence in primitive religions of various ethnic groups. During the period of Tibetan BonPo, its idea of heaven and earth matching each other and the conception of yin-yang union, as well as the worship of "sexual power" and women prevailed. In the "Genesis" of BonPo, it was said that Shapasanpochen and Qujemjemo were both born in cubic eggs formed by five original substances, who combined and generated beasts, animals and birds, and their noses contradicted each other (can be understood as the meaning of "mutual promotion and restraint") and gave birth to nine brothers and nine sisters. The nine brothers respectively parted themselves and generated a woman to be their wife, the nine sisters parted themselves and generated a man to be their husband, thus the big world came into being. This "Genesis" clearly contained the concept of yin-yang coincidence and the idea of sexual worship. The theory of "Triloka" structure in BonPo thought that the "heaven" was Ynag, and the "lower world" was Yin, and the "middle world" tamed yin and yang, which also reflected concept that the combination of yin and yang was the source of life. There were male and female sex organs in the sacrificial offering object and objects used in BonPo. The dharma-vessel "rgyang-bu" of BonPo was actually an abstraction of yin-yang combined figurine, representing the faith in reproduction and the pursuit of life. System BonPo also worshiped five deities with boundless magic power. The fourth of the five deities was named Gesuo, who was said to originally live in areas in Dese. He was a mountain god worshiped by inhabitants, whose appearance was like a ferocious yak, similar to Bull Demon King. In the original BonPo, the mountains and yaks were smybols of "vitality". Up to the period of system BonPo, mountain god like yak became the Dharmapala of BonPo, and the most capable one to subdue monsters, whose appearance was often made into double-body statue with many heads and many hands while embracing a woman. "Union of happiness" in Zangmi was based on
"Mahavairocana Tantra" and "Vajrasekhara Sutra", which inherited the female worship universally existing from primitive religion to BonPo, and formed accompanied by Buddhist doctrine, therefore producing a large number of artistic images of amphibious siamese twin Vajra.

\section{The CUltural CRystallization of Han, TiBEt AND INDIA-THANGKA "SIBAHUO"}

In many important ceremonies of Zangmi, this piece of Tancheng Thangka had been used to start, which was regarded as a fetish to subdue demon and, drive out evil spirits. "Siba" contained the meaning of "metempsychosis", "Huo" was a borrowed word of Chinese character "Hua (painting)", so this piece of Thangka was also called the "Painting of Metempsychosis", which contained the universe, The Nine Palaces and Eight Diagrams, representing all the time, direction and geography, reflecting the spirit of Tancheng Samsara, which was the spirit of the circle. According to legend, it was painted by Padmasambhava, the founder of the Tibetan Tantrism, by gathering the treasures for comfortable housing in Han, Tibet and India[5].

The circle in the center of this piece of Thangka was divided into nine palaces by the turtle back: there was a seed word on each color of red, yellow, white, green, black, and blue, representing the seasons in Tibetan calendar. Between the circle and the second round of circle was a radial eight-leaf lotus petal, on each petal painted a symbol of the Eight Diagrams, which consisted of Li, Kun, Dui, Gan, Kan, Gen, Zhen, Xun, respectively representing the fire, land, lake, heaven, water, mountain, thunder, and wind; the third round of circle was divided into twelve small cells, in each cell put an animal, representing twelve Earthly Branches or Zodiac, matching with the Heavenly Stems to evolve into a cycle of sixty years; outside the circle was a flame wall encircled by a fiend with four hands, placing the whole large circle in its own arms. It was Rahu in charge of the sun, moon and stars, as well as the time, commonly known as "TaiSuiXingJun", who rotated the wheel of life and death, symbolizing that change of season and time was contained in metempsychosis; in the upper right corner of the Tangka was the seed word Tancheng of Kalacakra, also known as Dharma- Mandala. It was composed of seven Sanskrit letters and three patterns, marking the unity of Kalachakra and its Tancheng, symbolizing the highest doctrine of Kalachakra. The pronunciation of these seven Sanskrit letters was successively Ya, Re, Wa, La, Ma, Qia and $\mathrm{Ha}$, and the first four letters successively meant Wuliang Palace's wind, fire, water and earth. The three patterns were the new moon, dot, and vertical strokes. Tancheng represented the Ten Directions, namely east, south, west, north, southeast, southwest, northwest, northeast, up and down and the whole time and space, universe and world consisting of year, month, day and hour; in the lower right corner was the Pratisedhana mantra wheel, which was to cover all the violation and arranged the five elements into nine palaces according to yin and yang; in the upper left corner was rebounding mantra wheel, which was to protect from all evil, obstacles, and drive out bad luck; in the lower left corner was the vowel and its origin mantra wheel, which was the vowel of all sounds and origin mantra, and could enhance good karma 
and good fortune, and absorb the essence of world. In the middle above Tancheng was Manjusri Bodhisattva with great wisdom and virtue, on the left was Vajrapani, and on the right was four-arm Avalokitesvara.

From this piece of Tancheng it could be clearly seen that Zangmi culture was also impacted by the inland culture. Such trace could also be found in the hour wheel of Tibetan Buddhism, which ingeniously combined with yin and yang, the core of Taoist culture, Tai Chi was embedded in the hour wheel. The two were in the circular kinetic energy of a concentric circle[6].

The research of relevant scholars shew that the cultural exchange between the Central Plains and Qinghai-Tibet Plateau had a long history and had not been interrupted. In the early phase Tibetan Empire, it was exchanged by ancient people of Qiang, Di, Tuyuhun and Jiarong, and the trace of the spread of the Central Plains' witch culture in Tibet[7]. In the 7th century, the "Method of Removing Evils" of the Central Plains was introduced to Tibetan Empire and translated into Tibetan, the title of which was "Bo Tang"[8]. The famous Tibetan scholar Wang Yao pointed out in his paper, "River Map, Luo Shu in Tibet", “... I believe the River Map and the "Nine Palaces" was spread to Tibet in the period of Tibetan Empire, ..." The philosophical thought represented by the Nine Palaces" or "River Map" had been finalized in the Tibetan society in Tang Dynasty."[9] The fact of such exchange was proved by a large amount of literature. In contrast, it was also possible for Zangmi Tancheng art which was fully formed in the late Tibetan Empire to absorb this culture, which was also in line with the actual situation. In the "Tantric Buddhism of Tibet", John Bloffield described Zangmi Tancheng in this way, "a very ancient yin-yang symbol of Chinese Taoists formed a useful prologue for the symbolism of Tantrism. Because it shew how the conclusions of practical science were sometimes transcended by the ancient sages, who intuitively reached these conclusions as they explored the depths of their knowledge. In addition, it directed to the basic principle of the Tibetan altars. Before Buddhism, it had been perfectly consistent with the cosmology of Tantrism, just like the content symbolized by it, which has already been widely confirmed by modern physicists. The central plan of Tancheng formed a very simple explanation of the world structure, which was connected with Chinese Taoist concept more widely known"[10]. It can be said as accidental that Zangmi Tanzhong and the Central Plains culture pursued for "unity of man and nature" at the same time, but it is more inevitable. As a kind of philosophical thought, the concept of "unity of man and nature" expressed the organic connection between man and heaven, and achieves the human's transcendence in the process of realizing the unity of man and nature.

\section{CONCLUSION}

As we all know, a nation is closely related to the traditional culture given to it by history, and a nation's traditional culture is formed on the basis of keeping learning, drawing on, absorbing and blending other national cultural wealth in the long-term historical development. Thus, each nation's culture is not a single, but multi-category, multi-school and multi-level. Zangmi Tancheng art is no exception, which is a brand new culture and art of Tibetan Buddhism formed after absorbing and integrating the original Tibetan BonPo culture and the inland culture on the basis of Indian Buddhism Tantric Tancheng. It is no longer Tancheng in Indian Tantric Buddhism, but also Tancheng different from Tangmi and Dongmi. It is walking toward to the world in the unique Tibetan art form to be understood and accepted by more people.

\section{REFERENCES}

[1] (Japan) Tanaka Komeito. Forty-two Silent Mandala in Dunhuang [J] translated by Liu Yongzeng. Dunhuang Research .2002.5.22.

[2] Yu Naichang.Fusion of Buddhism and BonPo, Zangmi and Its Art [J] Tibetology Research Group. Lhasa: Tibet People's Publishing House.

[3] SuoNanCaiRang. The history of Tibetan Tantrism [M]. Beijing: China Social Sciences Publishing House.1998.208.

[4] Same as [2]

[5] Gi Bu. Yang Dian. Mandala in Thangka [M]. Xi'an: Shaanxi Normal University Press. 2006.2-3.

[6] Yang Shihong. The Exploration on Similarity Frame between the Tibetan and Chinese Traditional Cultures. Journal of Northwest University for Nationalities (Philosophy and Social Sciences). Collected Works of Tibetan Studies, Mongolian Studies and Uighur Studies on Both Sides of the Taiwan Straits [J].

[7] Wu Jianli. A Tentative Study on the Footprints of Witch Culture and Taoist Culture in Qinghai-Tibet Plateau [J] Tibet Studies, 1996, (1).

[8] Yang Shihong. Interpretation and Origin Exploration of Dunhuang Ancient Tibetan Remnant Volume "Crow Caw Divination" [J]. Study on North-west Ethnic.1988. (2). 65.

[9] Wang Yao. "River Map, Luo Shu in Tibet [J] .Chinese Culture. (5). 136.

[10] (UK) John Bullfield. Tantric Buddhism of Tibet [M] translated by Geng Sheng. Beijing: China Tibetology Press .2005.74. 